\title{
Water transfer from Basilicata to Puglia: a technical, economic and institutional challenge
}

\author{
M. R. Mazzola \& G. Scordo \\ Dipartimento di Ingegneria Idraulica ed Applicazioni Ambientali, \\ Università di Palermo, Italy
}

\begin{abstract}
The necessity of supplying Puglia by transfer of water resources from Basilicata ( $250 \mathrm{Mm}^{3} /$ year mainly for civil use but also for agricultural and industrial uses) and another bordering region (Campania for $200 \mathrm{Mm}^{3} /$ year only for civil use) arises from the scarcity of water resources inside Puglia, where precipitation is very low $(400 \mathrm{~mm} /$ year), rivers are few and with limited watersheds and costal aquifers are overexploited with salt intrusion. Moreover recent droughts have pointed out the need for revising water supply policy in Puglia, looking for the increment of the transfer of water resources from Basilicata $\left(50 \mathrm{Mm}^{3} /\right.$ year) and Campania (32 $\mathrm{Mm}^{3} /$ year) and the development of feasibility studies of new supply options from other nearby regions (Abbruzzi and Molise) and/or another country (Albania). In this paper this plan and all these alternatives are described. In Italy the art.17 of the Galli Law, enforced in 1994, states that the deal between two regions for the transfer of water resources has to take into account not only the technical definition of the project, but also the environmental and social impacts, and the institutional assessment for the government of the resources and the management of the infrastructures. The recent application of the Water Framework Directive of the European Community, based on the principles of full cost recovery and polluters pay, introduces in this process the need for defining not only the financial costs of the proposed projects but also the environmental and the resources costs. In the paper the deal between Puglia and Basilicata for the management of existing and proposed infrastructures for the transfer of water resources is also described, which represents the first application in Italy of Galli Law (art.17) and of the principles of the EC Directive.

Keywords: water supply, water transfer, EC Directive, Galli Law.
\end{abstract}




\section{Present and forecasted water demands}

The problem of water supply of Puglia region is not new, owing to the very low precipitation (yearly mean value of $400 \div 450 \mathrm{~mm}$ ) and the presence of more than 4,0 million of inhabitants, large cultivated areas and important industrial areas with high water consumption firms.

The present water supply for civil uses in the region is $540 \mathrm{Mm}^{3} /$ year but the actual consumption is lower, because water losses are very high. A large program for water loss reduction has recently started by the Acquedotto Pugliese $\mathrm{SpA}$, which is the water company with the concession of water and wastewater services till 2018. The objective of this program is the reduction within 5 years of total losses to a level $30 \div 35 \%$, and the forecasted gross civil demand in year 2032 is $500,8 \mathrm{Mm}^{3} /$ year and the net demand is $383 \mathrm{Mm}^{3} /$ year, with per capita consumption of $250 \mathrm{l} / \mathrm{d}$.

As a consequence of lack of alternative water supply, the pressure for irrigation and civil uses has caused the overexploitation of coastal aquifers in Puglia, and one of the most important objective of the new water supply planning is to reduce groundwater withdrawals, implementing water saving irrigation methods, reusing wastewaters and replacing private wells with collective irrigation systems supplied by reservoirs. Actually the extension of collective irrigated districts is 75,517 ha with water demand of $199 \mathrm{Mm}^{3} /$ year, while the private irrigated areas are extended 286,885 ha with water demand of $362 \mathrm{Mm}^{3} /$ year. Starting from the present state, for the year 2032 an increment of the extension of collective irrigated districts to 117,911 ha has been stated with water demand of $301 \mathrm{Mm}^{3} /$ year, while the private irrigated areas do not change, and the total irrigated areas become 404,796 ha with water demand of $663 \mathrm{Mm}^{3} /$ year.

The present industrial demand for the whole region is $142 \mathrm{Mm}^{3} / \mathrm{year}$, with a strong concentration in the industrial area of Taranto, with water demand of $79 \mathrm{Mm}^{3} /$ year, partially supplied by reservoirs. The forecasted demand does not change considerably from the present one.

\section{Present water supply systems of Puglia}

The Puglia region is supplied mainly by water systems transferring resources from the bordering regions Campania, Basilicata and Molise (Fig. 1), rich in springs and rivers, while in Puglia it exists only the down stream of Ofanto river, whose upper stream is located in Campania and Basilicata. The only water supply sources located in Puglia are the coastal aquifers, which are overexploited as stated before. The three large water systems which transfer resources from the other regions are [5]:

- the Ionico-Sinni;

- the Ofanto-Sele-Calore;

- the Fortore.

The sources of the Ionico-Sinni water system (Fig. 1) are located in Basilicata and it supplies civil, agricultural and industrial users of Basilicata and Puglia, 
and to a less extent also of Calabria. The system is supplied by the flows of the rivers Sinni, Agri, Basento and Bradano, regulated in these reservoirs, with the following regulation capacity $\mathrm{K}\left(\mathrm{Mm}^{3}\right)$, mean inflow $\mathrm{I}_{\mathrm{M}}\left(\mathrm{Mm}^{3} /\right.$ year $)$, inflow with return time of 5 years $\mathrm{I}_{0.20}\left(\mathrm{Mm}^{3} /\right.$ year) and with return time of 20 years $\mathrm{I}_{0.05}$ $\left(\mathrm{Mm}^{3} /\right.$ year) (see table 1).

Table 1: $\quad$ Hydrologic features of Ionico-Sinni water system.

\begin{tabular}{|lcccc|}
\hline & $\mathrm{K}$ & $\mathrm{I}_{\mathrm{M}}$ & $\mathrm{I}_{0.20}$ & $\mathrm{I}_{0.05}$ \\
\hline Monte Cotugno & 433.0 & 347.8 & 247.3 & 158.8 \\
Pietra del Pertusillo & 142.0 & 279.8 & 179.6 & 109.7 \\
Camastra & 23.7 & 117.3 & 81.0 & 55.8 \\
San Giuliano & 90.2 & 115.0 & 42.1 & 13.7 \\
\hline
\end{tabular}

The comparison among $\mathrm{I}_{\mathrm{M}}, \mathrm{I}_{0.20}$ and $\mathrm{I}_{0.05}$ shows the strong variability of inflows and the possibility of severe droughts.

The Sinni sub-system aqueduct (186 km long; diameter $3000 \mathrm{~mm}$ ) transports raw water, and the resources for civil uses are treated in the "Parco del Marchese" plant (capacity of $6,0 \mathrm{~m}^{3} / \mathrm{s}$ ), located in Puglia close to the border with Basilicata. The release in a normal year (1999) has been $337,01 \mathrm{Mm}^{3}$, shared in this way among the different users (see table 2).

Table 2: $\quad$ Resources supplied by Sinni water sub-system.

\begin{tabular}{|lccc|}
\hline & Civil & Agricultural & Industrial \\
\hline Basilicata users & 12.79 & 149.92 & \\
Puglia users & 113.63 & 32.38 & 18.02 \\
Calabria users & 3.48 & 6.79 & \\
\hline
\end{tabular}

The resources regulated in the "Pietra del Pertusillo" reservoir for irrigation are released downstream, while those for civil use are treated in the Missanello plant (capacity of $3,6 \mathrm{~m}^{3} / \mathrm{s}$ ) located close to the reservoir and supplied by the discharge of a hydroelectric power plant. The Pertusillo sub-system main pipeline is $90 \mathrm{~km}$ long (diameters $1900 \div 2200 \mathrm{~mm}$ ) till the border with the Puglia region and after divides into two other pipelines supplying central $(111 \mathrm{~km}$; diameters $1000 \div 1900 \mathrm{~mm}$ ) and southern Puglia $(164 \mathrm{~km}$; diameters $1200 \div 1900$ $\mathrm{mm})$. The release in a normal year (1999) has been $154,15 \mathrm{Mm}^{3}$, shared in this way among the different users (see table 3 ).

The release of the Camastra sub-system in a normal year (1999) has been $14,02 \mathrm{Mm}^{3}$, shared in this way among the different users (see table 4).

The release of the San Giuliano sub-system in a normal year (1999) has been $42,90 \mathrm{Mm}^{3}$, shared in this way among the different users (see table 5). 
Table 3: $\quad$ Resources supplied by Pertusillo water sub-system.

\begin{tabular}{|lccc|}
\hline & Civil & Agricultural & Industrial \\
\hline Basilicata users & 3.15 & 42.79 & \\
Puglia users & 108.21 & & \\
\hline
\end{tabular}

Table 4: $\quad$ Resources supplied by Camastra water sub-system.

\begin{tabular}{|lccc|}
\hline & Civil & Agricultural & Industrial \\
\hline Basilicata users & 13.15 & 0.75 & 0.22 \\
\hline
\end{tabular}

Table 5: $\quad$ Resources supplied by San Giuliano water sub-system.

\begin{tabular}{|c|c|c|c|}
\hline & Civil & Agricultural & Industrial \\
\hline Basilicata users & 22.90 & & \\
\hline Puglia users & 20.00 & & \\
\hline
\end{tabular}

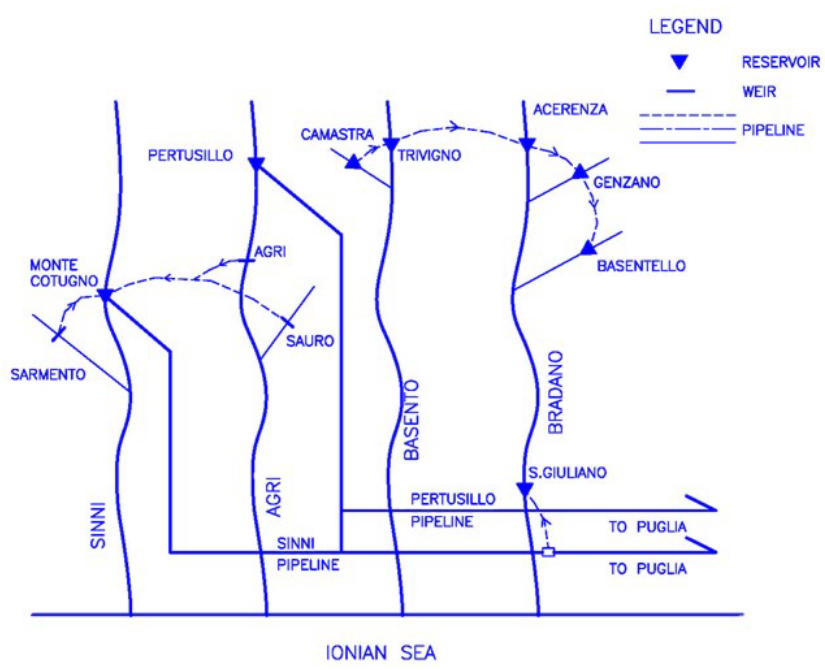

Figure 1: Ionico-Sinni water system.

The sources of the Ofanto-Sele-Calore water system (Fig. 2) are located mainly in Campania and also in Basilicata and Puglia and it supplies civil, agricultural and industrial users of Basilicata and Puglia, and to a less extent also of Campania. The system is supplied by the spring groups of "Caposele" and "Cassano Irpino" in Campania, and by the flow of the river Ofanto, whose watershed is interregional (Campania, Basilicata and Puglia). The mean diverted flow of the two spring groups is $155 \mathrm{Mm}^{3} /$ year, while the mean flow of the Ofanto river diverted by the Santa Venere weir is shown in table 6. 
Table 6: $\quad$ Resources features of Santa Venere weir.

\begin{tabular}{|lccc|}
\hline & $\mathrm{I}_{\mathrm{M}}$ & $\mathrm{I}_{0.20}$ & $\mathrm{I}_{0.05}$ \\
\hline Santa Venere & 230.4 & 165.1 & 112.0 \\
\hline
\end{tabular}

The Sele-Calore sub-system aqueduct has been built more than 80 years ago, its principal canal is $244 \mathrm{~km}$ long with tunnels more than $100 \mathrm{~km}$ long. It supplies only civil users, mainly in Puglia (147,2 $\mathrm{Mm}^{3} /$ year) but also in Campania (1,2 $\mathrm{Mm}^{3} /$ year) and Basilicata $\left(6,3 \mathrm{Mm}^{3} /\right.$ year $)$.

The water resources diverted by Santa Venere weir are regulated in these reservoirs (see table 7).

Table 7: $\quad$ Hydrologic features of reservoirs of Ofanto water system.

\begin{tabular}{|lcccc|}
\hline & $\mathrm{K}$ & $\mathrm{I}_{\mathrm{M}}$ & $\mathrm{I}_{0.20}$ & $\mathrm{I}_{0.05}$ \\
\hline Rendina (Basilicata) & 20.6 & 55.6 & 30.6 & 18.6 \\
M. Capaccioni (Puglia) & 50.0 & 2.3 & 0.7 & 0.2 \\
Locone (Puglia) & 105.0 & 11.8 & 5.2 & 3.3 \\
\hline
\end{tabular}

The resources diverted in a normal year (1999) have been $90,92 \mathrm{Mm}^{3}$, shared in this way among the different users (see table 8).

The resources for civil use from the Locone reservoir are treated in the closed homonymous plant (capacity of $1,5 \mathrm{~m}^{3} / \mathrm{s}$ ) and transported to central Puglia by a pipeline $86 \mathrm{~km}$ long and with diameters in the range $2400 \div 1600 \mathrm{~mm}$.

The sources of the Fortore water system (Fig. 3) are located in Puglia and Molise and it supplies civil agricultural and industrial users in Puglia. The system is supplied by the flow of the Fortore river, regulated in the Occhito reservoir (see table 10).

The release of the Fortore system in a normal year (1999) has been $190 \mathrm{Mm}^{3}$, shared in this way among the different users (see table 9).

Table 8: $\quad$ Resources supplied by Ofanto water sub-system.

\begin{tabular}{|lccc|}
\hline & Civil & Agricultural & Industrial \\
\hline Basilicata users & & 23.23 & 3.95 \\
Puglia users & 15.00 & 48.72 & \\
\hline
\end{tabular}

Table 9: $\quad$ Resources supplied by Fortore water sub-system.

\begin{tabular}{|lccc|}
\hline & Civil & Agricultural & Industrial \\
\hline Puglia users & 51.0 & 129.0 & 100.0 \\
\hline
\end{tabular}




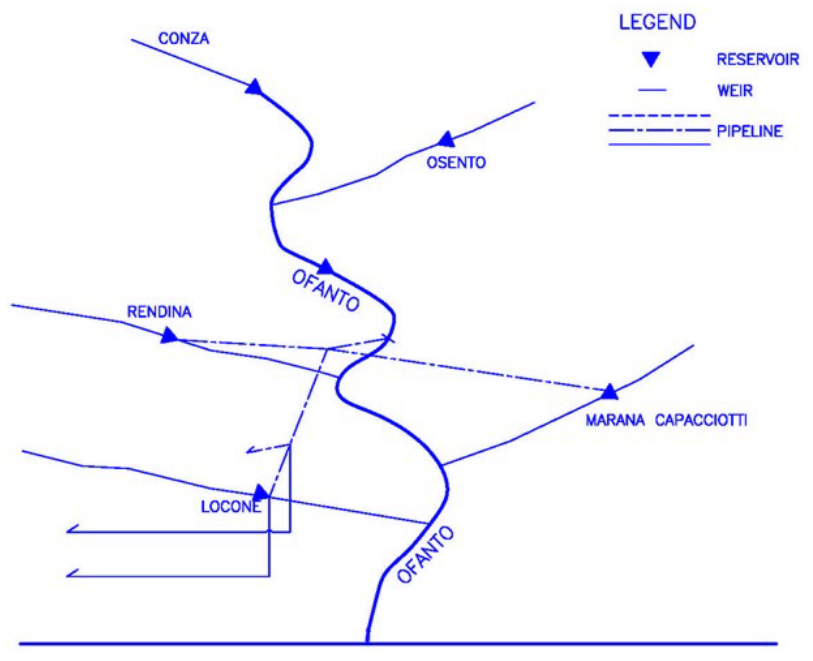

ADRIATIC SEA

Figure 2: Ofanto water sub-system.

Table 10: Hydrologic features of reservoirs of Fortore water system.

\begin{tabular}{|ccccc|}
\hline & $\mathrm{K}$ & $\mathrm{I}_{\mathrm{M}}$ & $\mathrm{I}_{0.20}$ & $\mathrm{I}_{0.05}$ \\
\hline Occhito & 247.5 & 137.3 & 94.2 & 60.5 \\
\hline
\end{tabular}

The resources for civil use from the Occhito reservoir are treated in the closed Finocchito plant (capacity of $2.4 \mathrm{~m}^{3} / \mathrm{s}$ ) and transported to northern Puglia by a pipeline $40 \mathrm{~km}$ long and with diameter of $1600 \mathrm{~mm}$.

\section{The development of the water supply systems}

The analysis of the demand pattern for the different uses till 2032 and the updating of the hydrologic forecasting recently developed have shown the opportunity of implementing new infrastructures to guarantee supply also during intense drought periods. Some of these infrastructures are under construction or have already been designed and their construction will start in few months, while others infrastructures are in the feasibility study stage.

The Ionico-Sinni water system supply will be increased in few years when the tunnels diverting Basento river streams down the Camastra reservoir and at the Trivigno wear section to the Acerenza and Genzano reservoirs located in the Bradano river watershed will be completed (see table 11).

The optimisation of the operation of these reservoirs, along with the other two located in Bradano watershed (Serra del Corvo and San Giuliano), will allow not only to widen the irrigation areas along the valley and close to the coast, but also to increase the supply security for the whole system. 


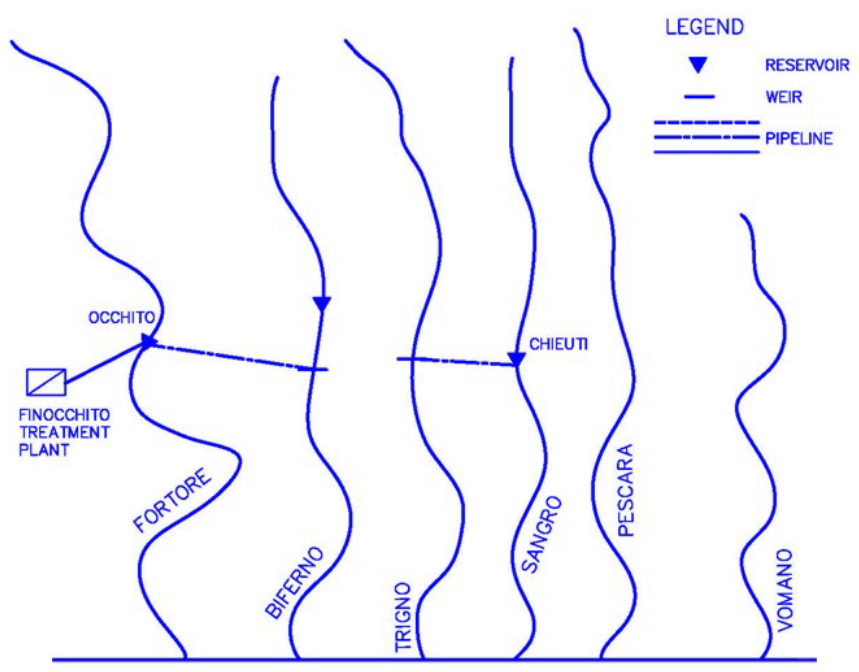

ADRIATIC SEA

Figure 3: $\quad$ Fortore water system.

Table 11: Hydrologic features of Trivigno weir and Acerenza, Genzano and Serra del Corvo reservoirs.

\begin{tabular}{|lcccc|}
\hline & $\mathrm{K}$ & $\mathrm{I}_{\mathrm{M}}$ & $\mathrm{I}_{0.20}$ & $\mathrm{I}_{0.05}$ \\
\hline Trivigno & 0.0 & 116.6 & 80.4 & 46.6 \\
Acerenza & 38.5 & 19.1 & 9.5 & 4.0 \\
Genzano & 52.9 & 5.4 & 2.3 & 0.8 \\
Serra del Corvo (Basentello) & 28.1 & 33.1 & 14.6 & 6.0 \\
\hline
\end{tabular}

Always in the Ionico-Sinni water system, also the water resources regulated in Monte Cotugno reservoir will be increased in few years, along with the supply security, when the construction of the weirs and the tunnels diverting into this reservoir the flows of rivers Sarmento, Agri at a section downstream of Pertusillo reservoir and Sauro will be completed. These weirs have (see table 12):

Table 12: $\quad$ Hydrologic features of Sarmento, Afri and Sauro weirs.

\begin{tabular}{|lcccc|}
\hline & $\mathrm{K}$ & $\mathrm{I}_{\mathrm{M}}$ & $\mathrm{I}_{0.20}$ & $\mathrm{I}_{0.05}$ \\
\hline Sarmento & 0.0 & 106.7 & 63.5 & 40.3 \\
Agri & 0.0 & 107.5 & 71.3 & 38.5 \\
Sauro & 0.0 & 46.1 & 30.1 & 17.7 \\
\hline
\end{tabular}


Another feasibility study proposed to increase the supply capacity of Monte Cotugno reservoir is to release downstream the water resources stored in the Cogliandrino reservoir located in the upper watershed of Sinni river, and presently diverted to the Noci river for hydroelectric energy production at the Castrocucco plant (see table 13).

Table 13: Hydrologic features of Cogliandrino reservoir.

\begin{tabular}{|ccccc|}
\hline & $\mathrm{K}$ & $\mathrm{I}_{\mathrm{M}}$ & $\mathrm{I}_{0.20}$ & $\mathrm{I}_{0.05}$ \\
\hline Cogliandrino & 10.1 & 120.1 & 79.0 & 42.8 \\
\hline
\end{tabular}

Some hydroelectric power plants in series have been proposed to partially compensate the loss of energy production. In any case the possibility of increasing water transfer from Monte Cotugno reservoir to irrigation areas and to Puglia is limited to $50 \div 60 \mathrm{Mm}^{3}$ by the size of existing pipeline, and to overcome this limit it is necessary another pipeline, with strong environmental and social problems.

The Ofanto-Sele Calore water system supply will be increased in the next years by the resources regulated in the Conza reservoir located in Campania (see table 14).

Table 14: Hydrologic features of Conza reservoir.

\begin{tabular}{|ccccc|}
\hline & $\mathrm{K}$ & $\mathrm{I}_{\mathrm{M}}$ & $\mathrm{I}_{0.20}$ & $\mathrm{I}_{0.05}$ \\
\hline Conza & 63.0 & 90.7 & 62.1 & 40.2 \\
\hline
\end{tabular}

The new treatment plant will have a capacity of $1,5 \mathrm{~m}^{3} / \mathrm{sec}$, and a yearly volume production of $32 \mathrm{Mm}^{3}$ distributed in the central Puglia by an already existing $175 \mathrm{~km}$ long pipeline, with diameters in the range $2400 \div 1600 \mathrm{~mm}$.

To increase water supply of the Fortore water system supply for northern Puglia a feasibility study of the diversion from Biferno river in Molise to Occhito reservoir has been carried out (Fig. 3). It has shown the possibility of transferring $20 \div 25 \mathrm{Mm}^{3} /$ year with limited environmental problems.

Always for the same system, other two very complex projects have been proposed. The first one is the diversion of water resources from Sangro and Trigno rivers, whose watersheds are in Molise and Abruzzo regions, regulated in the existing Chieuti reservoir located in Molise $\left(\mathrm{K}=112,3 \mathrm{Mm}^{3}\right)$ to Finocchito treatment plant and Locone reservoir, by pipelines $163,7 \mathrm{~km}$ long and with diameters in the range $3000 \div 1000 \mathrm{~mm}$. The preliminary feasibility study should define amount of water to divert, costs and environmental effects to verify the possibility of an agreement among Puglia, Molise and Abruzzo.

The other project is the transfer of $200 \div 260 \mathrm{Mm}^{3} /$ year from Sangro, Pescara and Vomano rivers in Abruzzo to the Finocchito treatment plant by three pipelines $125,7 \mathrm{~km}, 165,9 \mathrm{~km}$ and $191,5 \mathrm{~km}$ long in a large part submarine. The project is expansive, also because it is necessary to increase the capacity of water 
treatment plant and to realize new pipelines to transport resources also to central Puglia.

Furthermore the preliminary analysis of potential irrigation demand in northern Puglia and of environmental effects are key points for the evaluation of project benefits and costs and the subscription of the agreement between Puglia and Abruzzo.

Another proposed project for the supply of Puglia is a pipeline $212 \mathrm{~km}$ long (85 km submarine) transferring $150 \mathrm{Mm}^{3} /$ year from Albania to southern Puglia, but also in this case a preliminary feasibility study, with cost-benefit and alternative analyses, should be carried out before going further in the project.

Since many of these projects are long term ones, the Puglia administration has analysed the possibility to build three desalination plants to reduce the negative effects of long droughts as that occurred in the $2000 \div 2002$ years. These plants should be located close to the cities of Bari $\left(20 \mathrm{Mm}^{3} /\right.$ year $)$, Brindisi $\left(20 \mathrm{Mm}^{3} /\right.$ year) and Taranto $\left(18 \mathrm{Mm}^{3} /\right.$ year). The first two treat sea water, while the third treats brackish spring water.

\section{Institutional framework of interregional agreements}

As stated before the development of interregional water transfer projects involves not only technical aspects but also institutional and economic ones. The institutional framework of interregional water transfers in Italy is stated in the article 17 of the national Law n. 36 enforced in January 1994 [11], concerning the reorganization of civil water services, and also in the latest environmental legislation [4]. The law states that, when in the river basins planning the analysis of water demand-supply balance could imply water transfers among different regions and river basins, the concerned Regions and River Basins Authority promote Program Agreements, which are approved by the National Government. The interregional water transfer infrastructures are defined of national interest and State can financially support investment and operation costs. In each agreement are defined the criteria and procedures for the realization and management of proposed measures or infrastructures, which should respect in any case the principle of environmental, economic and social sustainability. The feasibility studies of measures and infrastructures proposed in the agreement should contain [3]:

- present and forecasted demand-supply analysis for the different uses;

- energetic state balance of water resources before and after the transfer;

- analysis of resources quality state before and after the transfer;

- environmental impact evaluation;

- financial and economic benefit - cost analysis.

In the agreement should be also defined the financial plans for the realization of proposed measures and infrastructures, with the identification of public and private funds, and subjects involved in their realization and management.

The concepts of article 17 of Law 36/94 have been confirmed in the EC Water Framework Directive 2000/60, which has introduce the following principles: 
- Integrating water resources management at the hydrographical district scale, taking into account at the same time the qualitative aspects of surface and ground waters to reach a satisfactory level of environmental protection

- Analyzing the characteristics of the hydrographical district, the impact of human activities and developing the economic analysis of water resources uses.

The economic analysis is based on the principles of "polluter pays" and "full cost recovery" of water services, also if each State could subsidize partially the costs for some users, like the agricultural ones, but the social reasons of this policy should be clearly stated in the management plans. Three main components of costs are defined $[6,7]$,

- Financial costs include the costs of providing technological services and the costs of administering these services; they include operation and maintenance costs, capital maintenance costs, capital cost (principal and interest payment, and return on equity where appropriate)

- Environmental costs represent the costs of damage that water uses impose on the environment and ecosystems and those that use the environment (e.g. recreation)

- Resource costs represent the costs of foregone opportunities, which other uses suffer in the present and in the future due to the depletion of the resource beyond its natural rate of recharge or recovery

The recovery of costs should be fair and transparent and it has to be to be disaggregated into at least industry, households and agriculture. Each country should define water pricing policies which stimulate users within 2010 to consume efficiently water resources contributing to the environmental objectives of the Directive. Within the same date civil, agricultural and industrial users have to be "fairly" charged of the full costs of water services, but the member States could be take into account the social, environmental and economic aspects of recovery, as well as geographic and climate regional conditions.

$\mathrm{T}$ he enforcement framework of these concepts has been recently developed by the European Commission [9], and there is a vast literature on the different aspects of this subject $[2,10,12,13]$.

\section{Institutional and economics aspects of the Puglia-Basilicata Program Agreement}

According to article 17 of Law 36/94 and following the principles of EC Directive 2000/60, of which at that time a draft was already known, the regions Puglia and Basilicata and the Ministry for Public Works signed on the fifth of August 1999 the Program Agreement concerning the management of the water resources transferred from Basilicata to Puglia by the Ionico-Sinni water system [1]. This agreement is the first application in Italy of this legislation and it is probably the most complete example not only for the system technical complexity but also because the infrastructures already built have strong environmental and social impacts. 
The agreement is based on the cooperation between the two regions and its objectives are stated in this way:

- definition of the water resources balance and planning of the system till 2015;

- identification of existing infrastructures of common interest forming the raw water system;

- establishment of permanent cooperative executive body for the planning of actions and monitoring of the Program Agreement;

- reform of the existing authorities and public water agencies;

- definition of raw water tariff, including financial, environmental and resource costs;

- implementation of actions of water demand control, reducing losses and wastewater reuse in the different uses and of environmental control of coastal areas for retrogradation and aquifer salt intrusion;

- identification of measures and infrastructures to complete and to improve the existing water system;

- development of feasibility study to increment system water supply and transfer to Puglia;

- definition of guidelines for water resources management and priority of reduction measures for the different users during droughts.

The technical aspects of this agreement have been described in the previous sections of this presentation. In this section we focus our attention on the problem of institutional cooperation, reform of authorities and agencies and raw water tariff, looking at the actual state of application of the Agreement.

The article 5 of the Agreement provides the institution of the Authority of the Government of Water Resources, made up by the Minister of Public Works and the Presidents of the Regions Puglia and Basilicata or their delegates, with the participation of the Secretary of River Basin Authorities competent for the water system. The Authority is chaired alternately by one of the President of the two regions and among the other tasks at the end of February in each year it verifies the resources stored in the reservoirs in order to define the releases for the year for the different users and eventually the demand reduction measures to face shortages. The Authority has been constituted after the signature of the Agreement and it worked really well during the long and severe drought of years 2001-2002, smoothing the negative effects of shortages on final consumers.

In the article 7 of the Agreement the two Regions undertake the engagement of reforming the organization of the existing River Basins Authorities reducing the number to only two Authorities whose boundaries are consistent with water system boundaries. These reforms have been carried out and now the Basilicata River Basin Authority includes the Ionico-Sinni water system, while the Puglia River Basin Authority includes the Ofanto water sub-system.

In the article 13 of the Agreement and in the quoted Attachment 5 the two Region and the Ministry agree on the reform of existing water public corporations (Acquedotto Pugliese for civil services and EIPLI for raw water services) in three new stock companies, two for the civil water services in the regions and one for the management of common raw water system. At the 
present time the two companies for the civil water services have been started, that is Acquedotto Pugliese S.p.A. in Puglia and Acquedotto Lucano S.p.A. in Basilicata. Instead for the management of raw water system the reform of EIPLI has not been carried out by the Ministry of Agriculture, and in the meantime the Basilicata Region has started a new stock company (Acqua S.p.A) to manage and to develop the whole regional system supplying raw waters.

The shareholding of this society is open to other bordering regions, and in any case the control will remain public because the main function of this society is the minimization of the financial costs of raw water system and moreover the society could cover the needs of technical assistance of River Basin Authorities and Regions for the definition and implementation of water resources policies. To avoid the possible distortions of the natural monopoly in which this society operates, its structure should be very light and well qualified, and market competition is introduced by contracting-out the operation and maintenance services and realizing the new infrastructures by contracts for public works and project finance when it is convenient.

Also if in the Attachment 3 of the Agreement, which defines the water resources government policies and the programmatic guidelines, is underlined the opportunity of reforming the existing public subjects charged of irrigation and industrial water services, that is Land Reclamation Agencies and Industrial Development Agencies, nothing has been done in practice to implement their efficiency. The unsuccessful reforms of these subjects and EIPLI and the possible clash of competences of EIPLI and Acqua S.p.A are weak points in the process.

The article 15 of the Agreement has stated that the total production costs of raw water had to be established by the Authority of the Government of Water Resources within the end of year 2000. These costs have to take into account:

- financial costs;

- environmental costs;

- resources costs.

As stated in the article 6 of the Agreement a working group has been charged to propose how to apply these concepts. It produced in July 2002 a very valuable document from the theoretical point of view, but with limited applicability for lack of information and uncertainties.

As a matter of fact information on present operation and maintenance costs are incomplete and partially unreliable, and the estimated value of $0.021 € / \mathrm{m}^{3}$ may be significantly different from the real one; consequently the definition of these costs has been postponed.

Environmental costs have been estimated as a percentage of the following costs:

- maintenance of watersheds upstream the reservoirs (50\%);

- maintenance of hydrographical networks upstream the reservoirs (50\%);

- tertiary level in the wastewater treatment plants upstream the reservoirs ( $30 \%$ of the total treatment costs);

- quantitative and qualitative monitoring (60\%); 
- maintenance of hydrographical networks downstream the reservoirs $(20 \%)$;

- defence from hydrogeological risks downstream the reservoirs (50\%);

- protection from erosion of Ionian coast $(60 \%)$.

The estimated unit environmental cost is $0,055 € / \mathrm{m}^{3}$.

The document introduces the energy recovery costs for Basilicata as a measure of resources costs. Owing to the lack of specific information, as first approximation of the actual one in the document the estimated unit electric energy recovery cost is $0,024 € / \mathrm{m}^{3}$, that is equal to the double of yearly irrigation pumping costs in Basilicata, whose value is defined in the fifth paragraph of article 15 of the Agreement, to take into account also the other pumping costs in Basilicata and the loss of potential production of hydroelectric energy.

In the absence of any indication, the document proposes also to estimate the other resource costs as a percentage of $10 \div 20 \%$ of the sum of financial, environmental and energy recovery ones.

The document tackles also the problem of cost sharing among the different users, and proposes to apply mean tariff to civil users, to increment tariff for industrial ones and to reduce it for agricultural users. The proposed subsidies for rural sector are justified for its weakness and the social and environmental benefits induced by irrigation, especially in order to contrast the desertification process in these areas.

The discussion about document proposals has been complicated and long, and only the $25^{\text {th }}$ May 2004 the Authority of the Government of Water Resources has approved a document on water raw tariff which states the following.

- Provisional mean raw water tariff excluding financial costs for years 2003 and 2004 is $0,055 € / \mathrm{m}^{3}$ and for year 2005 is $0,075 € / \mathrm{m}^{3}$ and it is applied to the water resources assigned to each region; for the years $2000 \div 2002$ the environmental costs of $35 \mathrm{M} €$ are covered by national funds.

- Each region can differentiate tariffs among different users within the region, and eventually reducing them by regional funds in order to subsidize sectors, like the rural one.

- Document on raw water tariff should be revised in order to reduce estimate uncertainties, and within the end of July 2004 the financial costs should be fixed.

Probably till the end of year 2005 raw water tariff will be not applied for irrigation by both regions, and this is a weak point in the process. In order to respect the EC Directive principle of "fairly" charging of the full costs of water services to each user, it is worth wishing for the application of this principle at least for the financial costs.

\section{Conclusions}

The need of transferring most of water resources consumed by Puglia from other regions arose till the past century, and many complex water supply systems have 
been realized. The management of this system is not simple and technical, economic and institutional aspects have to be faced.

The physical and hydrological features of Ionico-Sinni, Ofanto-Sele-Calore and Fortore water systems have been described in the presentation along with the proposed infrastructures to increment availability of water resources and supply security in Puglia. The management of Ionico-Sinni water system is the more complex one, owing to the technical, environmental and social problems connected with the existing storage and transport infrastructures, and the presence of civil, industrial and agricultural users of Puglia and Basilicata.

To solve these problems the two Regions and the National Ministry of Public Works have signed in 1999 a Program Agreement, that is the first application of national regulations on this field. The Agreement activities are also one of the first applications in Italy of the EC Water Framework Directive 2000/60, which introduces economic aspects in the water resources management of a river basin and the need of planning at hydrographical district scale, extending the concept of integrated river basin management.

The experience of this Agreement shows that it works really well in the coordination of the Regions in the water resources management by the institution of the Authority of the Government of Water Resources, with strong benefits especially during severe shortages and more efficient planning of new infrastructures. Positive effects have been partially the reform of the existing water public corporations for civil services, but till now it has failed in reforming the raw water supply public corporation EIPLI, and the existing public subjects charged of irrigation and industrial water services, that is Land Reclamation Agencies and Industrial Development Agencies. The possible clash of competences of EIPLI and of new society Acqua S.p.A is another weak point in this process. The definition of the raw water tariff has been a long and complicated process and only the $25^{\text {th }}$ May 2004 the Authority of the Government of Water Resources has approved a document on provisional water raw tariff for the period 2000-2005. The weak point is that has been postponed the application at the rural sector of the EC Directive principle of "fairly" charging of the full costs of water services to each user.

\section{References}

[1] "Accordo di Programma fra Basilicata, Puglia e il Ministero dei Lavori Pubblici (Art.17 L.36/94)", Rome, 1999, in Codice della Difesa del Suolo e delle Risorse Idriche, Collana Ed. di Studi e Ricerche della Autorità Interregionale di Bacino della Basilicata, vol. 1, Potenza, Italy, May 2002

[2] Agencie de l'eau Seine-Normandie, "Proceedings of the Second international workshop on implementing economic analysis in the Water Framework Directive Opening the Black Box “, Paris; February 2005

[3] Decreto Presidente Consiglio Ministri 4 marzo 1996 "Disposizioni in materia di risorse idriche", Rome, Italy, 1996

[4] Decreto Legislativo 3 aprile 2006, n.152 "Norme in materia ambientale", Rome, Italy, 2006 
[5] Di Santo A., Ranieri M., "Studi propedeutici all'Accordo di Programma Puglia-Basilicata per la gestione delle risorse idriche, L'Acqua, 2000(2), pp. $65 \div 76$

[6] European Commission, "Communication from the Commission to the Council, the European Parliament and the economic and social committee concerning the pricing policies for enhancing the sustainability of water resources", COM (2000)477 final, Brussels, Belgium, October 2000

[7] European Commission, "Commission Staff Working Paper. Water pricing policies in theory and practice. Annex E to the Communication COM (2000)477 final, SEC (2000) 1238, Brussels, Belgium, October 2000

[8] European Commission, “ Water Framework Directive 2000/60/CE, Brussels, Belgium, October 2000

[9] European Commission, Working Group 2.6 WATECO, "Economics and the Environment. The implementation challenge of the water framework directive. A guidance document n ${ }^{\circ}$ ", Luxemburg, 2003

[10] Gibbons D. C., "The economic value of water" Resources for the future, Washington D.C., USA, 1986

[11] Legge 5 gennaio 1994, n.36 "Disposizioni in materia di risorse idriche", Rome, Italy, 1994

[12] Pearce D.W., Mourato S., Atkinson G., "Recent development in environmental cost-benefit analysis", Draft, OECD, Paris, France, September 2004

[13] Young R. A., "Measuring economic benefits for water investments and policies", World Bank, technical paper n.338, Washington D.C., USA, 1996 